\title{
Implementasi Metode Breadth First Search danVikor pada Aplikasi Diagnosa Kerusakan Hardware Komputer
}

\author{
Halim Agung \\ Faculty of Technology and Design \\ Bunda Mulia University \\ Jl. Lodan Raya No. 2 Jakarta 14430, Indonesia \\ hagung@bundamulia.ac.id
}

\author{
Nico Yunus Marselinus \\ Faculty of Technology and Design \\ Bunda Mulia University \\ Jl. Lodan Raya No. 2 Jakarta 14430, Indonesia
}

\begin{abstract}
Abstrak- Kerusakan pada komputer memiliki berbagai macam kerusakan dari kerusakan ringan maupun berat yang menyebabkan banyak service center yang banyak dibuka. Akan tetapi seiring banyaknya service center yang dibuka, banyak pula service center yang melakukan penipuan pada pelanggan. Untuk mengatasi hal tersebut dibangunlah aplikasi yang digunakan dalam pencarian diagnosa kerusakan komputer yang menggunakan metode breadth first search dan vikor. Pengujian yang dilakukan adalah dengan melakukan uji coba aplikasi dengan menggunakan metode black box. Dari hasil pengujian yang dilakukan dapat diambil kesimpulan bahwa algoritma Breadth First Search dapat melakukan proses pencarian solusi melalui pemilihan gejala-gejala yang ada, kemudian metode Vikor dapat melakukan proses rating untuk merekomendasi solusi yang akan dilakukan oleh user dengan tingkat keberhasilan 99\% sesuai dengan rekomendasi ahli.
\end{abstract}

Kata Kunci: aplikasi diagnosa, breadth first search, hardware komputer, vikor.

\section{INTRODUCTION}

Komputer merupakan teknologi mutakhir yang digunakan banyak orang untuk melakukan banyak kegiatan. Komputer terbagi dalam tiga komponen yaitu hardware, software, dan brainware. Pada komputer sering terjadi kerusakan pada software dan hardware, pada kerusakan ini biasa banyak pengguna atau brainware yang tidak mengerti solusi dari kerusakan tersebut. Biasanya penggunakan pihak ketiga yang lebih ahli dalam persoalan tersebut dan membayar mahal untuk memperbaiki kerusakan itu.

Di dalam penggunaannya, hardware komputer tidak luput dari kerusakan atau masalah, meskipun kerusakan itu adalah kerusakan kecil dan peranan seorang teknisi pun sangat di butuhkan terutama bagi para pengguna atau pemilik komputer yang tidak mengetahui penyebab-penyebab kerusakan dan cara memperbaiki di saat komputer mengalami kerusakan. Sangat disayangkan jika kerusakan yang terjadi hanyalah kerusakan kecil yang semestinya dapat di perbaiki sendiri. Sementara, waktu untuk menunggu perbaikan cukup lama dan membutuhkan biaya yang cukup besar..

Aplikasi ini akan menentukan solusi terbaik dari beberapa solusi yang diberikan untuk dilakukan user, dimana setiap solusi akan diberikan rating. Dalam proses rating tersebut aplikasi ini menggunakan metode Breadth First Search dan metode VIKOR. VIKOR (VlseKriterijumska Optimizacija I Kompromisno Resenje dalam bahasa Serbia, yang artinya Multicriteria Optimization and Compromise Solution) adalah metode ranking dengan menggunakan indeks peringkat multikriteria berdasarkan ukuran tertentu dari kedekatan dengan solusi yang ideal. Metode VIKOR merupakan salah satu metode yang dapat dikategorisasikan dalam Multicriteria Decision Analysis. Metode VIKOR dikembangkan sebagai metode multicriteria decision making untuk menyelesaikan pengambilan keputusan bersifat diskrit pada kriteria yang bertentangan dan non-commensurable(Opricovic and Tzeng 2007).VIKOR adalah sebuah metode untuk optimisasi/optimalisasi kriteria majemuk dalam suatu sistem yang kompleks (Khezrian, Wan Kadir et al., 2011).Konsep dasar VIKOR adalah menentukan ranking dari sampel-sampel yang ada dengan melihat hasil dari nilai-nilai sesalan atau regrets $(\mathrm{R})$ dari setiap sampel. Metode VIKOR telah digunakan oleh beberapa peneliti dalam MCDM, seperti dalam pemilihan vendor (Datta, Mahapatra et al., 2010).

Sedangkan pencarian dengan Breadth First Search menggunakan teknik di mana langkah pertamanya adalah root node diekspansi. Setelah itu dilanjutkan semua successor dari root node juga diperluas. Hal ini terus dilakukan berulang-ulang hingga node pada level paling bawah yang sudah tidak mempunyai successor lagi (Budiharto dkk,2014). Keuntungan dari metode ini tidak menemui jalan buntu dalam pencarian, jika ada satu solusi maka Breadth First Search akan menemukannya, dan jika ada lebih dari satu solusi, metode Breadth First Search akan menemukan solusi 
minimum (Budiharto dkk,2014). Kekurangan metode ini memerlukan memori yang cukup banyak dan membutuhkan waktu yang cukup lama karena metode ini mencari dari node ke node atau dari pohon ke pohon (Budiharto dkk,2014).

Algoritma BFS menggunakan algoritma tunggal yang memanggil setiap node pada pohon pencarian. Algoritma BFS melakukan looping dari setiap node ke node yang lain sampai tidak menemukan titik yang belum di kunjungi (C.E. Leiserson and T.B. Schardl, 2010).

\section{METHODOLOGY}

Dalam penelitian ini metode yang akan digunakan adalah metode Breadth First Search dan Vikor. Metode Breadth First Search adalah suatu metode pencarian yang mencari pada setiap pohon menuju akarnya sampai akar-akar pada setiap pohon itu habis, dengan kata lain tidak memiliki akar lagi.

Metode Vikor adalah metode peringkatan dengan menggunakan indeks peringkat multikriteria berdasarkan ukuran tertentu dari kedekatan dengan solusi yang ideal. Konsep dasar Vikor adalah menentukan ranking dari sampel-sampel yang ada dengan melihat hasil dari nilai-nilai sesalan atau regrets $(\mathrm{R})$ dari setiap sampel.

Berikut ini adalah contoh pencarian kesimpulan pada sistem pakar hardware komputer dengan metode breadth first search. Proses pencarian dilakukan pada satu jenis masalah "komputer mati total" dan user memilih gejala yang ditampilkan bedasarkan masalah tersebut dengan penjelasan sebagai berikut:

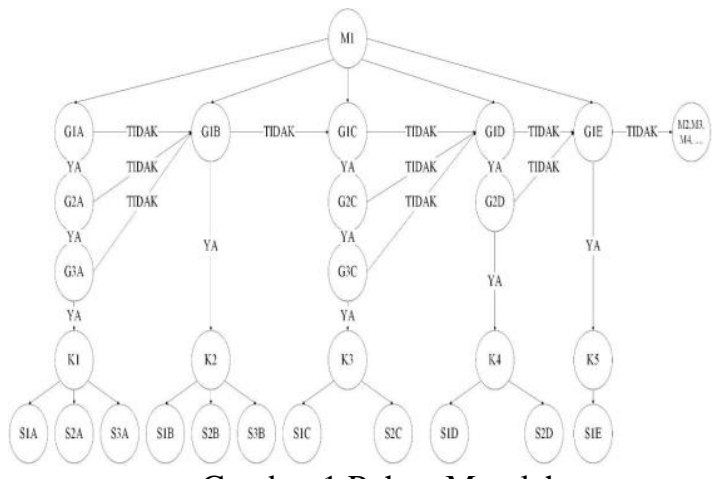

Gambar 1 Pohon Masalah

Dilihat dari Gambar Pohon Masalah diambil contoh kasus, user memilih "M1" sebagai masalah utama yang menjadi masalah pertama pada pohon masalah.

- Ketika "M1" dipilih akan keluar "G1A" sebagai kepala pohon gejala, di sini user dapat memilih "ya" atau "tidak".

- User memilih "ya" maka akan muncul "G2A", di sini user dapat memilih lagi antara "ya atau "tidak".

- User memilih "tidak" dan akan muncul "G1B" sebagai kepala pohon gejala yang kedua.

- Kemudian user memilih "ya" dan akan muncul "K2" yaitu kesimpulan dari "G1B".

- Karena user mendapat "K2" maka akan muncul juga "S1B", "S2B", dan "S3C" sebagai solusi dari "K2".

Penjelasan sebagai berikut:

- M1, M2, M3, M4, dan M... adalah kepala masalah yang akan menampilkan kepala pohon gejala.

- G1A, G1B, G1C, dan G1... adalah kepala pohon gejala yang akan menampilkan akar gejala dari kepala pohon gejala.

- G2A, G3A, G2B, G3B, dan G... adalah akar dari kepala pohon gejala masing-masing.

- $\mathrm{K} 1, \mathrm{~K} 2, \mathrm{~K} 3$, dan $\mathrm{K}$... adalah kesimpulan yang diambil berdasarkan kepala gejala, dan akar gejala yang dipilih.

- $\quad$ S1A, S2A, S3A, S1B, S2B, dan S... adalah solusi dari setiap kesimpulan yang didapat. Kemudian dari solusi yang didapat akan mendapat rating menggunakan metode VIKOR.

Berikut ini adalah contoh perhitungan manual menggunakan metode Vikor dalam ranking. Proses ranking dilakukan tiga alternatif solusi seperti pada Gambar 2.1 "S1A", "S2A", dan "S3A" dengan tiga kriteria dengan penjelasan sebagai berikut:

A. Penjelasan kriteria

1) Termudah dilakukan. Penilaian diambil dari tingkat kemudahan solusi untuk dilakukan oleh user.

2) Biaya termurah. Penilaian dilakukan berdasarkan biaya yang dikeluarkan jika melakukan solusi tersebut.

3) Disarankan oleh ahli. Penilaian dilakukan berdasarkan saran dari ahli komputer.

B. Alternatif solusi

$\mathrm{S} 1 \mathrm{~A}=$ Cek kabel power pada power supply, apakah kendor atau tidak. S2A = Cek knop tombol on/off pada bagian belakang power supply, dan pastikan dalam keadaan on. S3A = Cek power supply masih hidup atau tidak, dengan cara menghubungkan pin dengan tembaga sesuai gambar, jika menyala coba pasangkan kembali dengan benar ke komputer.

C. Kriteria

$\mathrm{Kr} 1=$ Termudah dilakukan, $\mathrm{Kr} 2$ = Biaya termurah, $\mathrm{Kr} 3$ = Disarankan oleh ahli

Tabel 1 Tabel Data Nilai Kriteria

\begin{tabular}{|l|l|l|l|}
\hline & Kr1 & Kr2 & Kr3 \\
\hline A1 & 90 & 70 & 100 \\
\hline A2 & 80 & 60 & 80 \\
\hline A3 & 70 & 60 & 40 \\
\hline
\end{tabular}

Keterangan :

- Nilai yang berwarna merah dan digaris bawahi 
merupakan nilai terbesar dalam satu kriteria.

- Nilai yang dipertebal dan dimiringkan merupakan nilai terkecil dalam satu kriteria.

Seperti yang ditunjukkan pada Tabel 2.1 pada, masing-masing kriteria penilaian memiliki bobot nilai yang berbeda. Pemberian bobot kriteriadilakukan berdasarkan derajat kepentingan dari masing-masing kriteria. Bobot kriteria diberikan dalam bentuk desimal yang merepresentasikan persentase dari masing-masing kriteria berdasarkan nilai kepentingannya dengan jumlah total dari semua bobot kriteria adalah satu.

Pemberian nilai bobot kriteria dilakukan dengan memperhatikan tingkat kepentingan dari masingmasing kriteria. Untuk kriteria dengan tingkat kepentingan yang lebih tinggi maka nilai bobot kriterianya akan lebih tinggi dibandingkan dengan kriteria yang lain. Dan untuk kriteria dengan tingkat kepentingan yang lebih rendah maka nilai bobot kriterianya akan lebih rendah. Kriteria dengan tingkat kepentingan yang sama maka akan memiliki nilai bobot kriteria yang sama. Contoh :

- $\mathrm{K} 1$ memiliki tingkat kepentingan sebesar 50\% $(10 / 100=0.5)$

- $\mathrm{K} 2$ memiliki tingkat kepentingan sebesar $30 \%$ $(20 / 100=0.3)$

- $\mathrm{K} 3$ memiliki tingkat kepentingan sebesar $20 \%$ $(40 / 100=0.2)$

Tabel 2 Tabel Bobot Kriteria

\begin{tabular}{|l|l|l|l|}
\hline & $\mathrm{Kr} 1$ & $\mathrm{Kr} 2$ & $\mathrm{Kr} 3$ \\
\hline Bobot & 0.5 & 0.3 & 0.2 \\
\hline
\end{tabular}

Dari data nilai solusi pada Tabel 2.1 dan data bobot kriteria pada Tabel 2.2 maka akan dilakukan perhitungan manual menggunakan metode Vikor untuk mendapatkan hasil perangkingan dari metode.

Perhitungan metode Vikor dalam melakukan proses ranking dengan tiga alternatif solusi dan tiga jenis kriteria.

A. Alternatif solusi

$\mathrm{S} 1 \mathrm{~A}=$ Cek kabel power pada power supply, apakah kendor atau tidak. S2A = Cek knop tombol on/off pada bagian belakang power supply, dan pastikan dalam keadaan on. S3A = Cek power supply masih hidup atau tidak, dengan cara menghubungkan pin dengan tembaga sesuai gambar, jika menyala coba pasangkan kembali dengan benar ke komputer.

B. Kriteria

$\mathrm{Kr} 1=$ Termudah dilakukan, $\mathrm{Kr} 2$ = Biaya termurah, $\mathrm{Kr} 3$ = Disarankan oleh pakar

Normalisasi Matriks

$\mathrm{Rij}=\frac{x * j-x i j}{x * j-x \prime j}$

Rumus

1. Normalisasi
Matriks Vikor

Keterangan :

$\mathrm{Xij}=$ Nilai data sampel $\mathrm{i}$ kriteria $\mathrm{j}$

( $\mathrm{i}=\mathrm{A} 1, \mathrm{~A} 2, \mathrm{~A} 3)$

( $\mathrm{j}=\mathrm{K} 1, \mathrm{~K} 2, \mathrm{~K} 3$ )

$\mathrm{X}^{* \mathrm{j}}=$ nilai terbaik dalam satu kriteria

$\mathrm{X}^{\prime} \mathrm{j}=$ nilai terburuk dalam satu kriteria

Dari data nilai solusi akan dilakukan normalisasi data nilai berdasarkan Rumus 1 .

Perhitungan normalisasi data alternatif solusi A1.

1) $\mathrm{Kr} 1$

2) $\mathrm{Kr} 2$

$$
R_{A 1}=\frac{90-90}{90-70}=\frac{0}{20}=0
$$

3) $\mathrm{Kr} 3$

$$
R_{A 1}=\frac{70-70}{70-60}=\frac{0}{10}=0
$$

$$
R_{A 1}=\frac{100-100}{100-40}=\frac{0}{60}=0
$$

Dengan langkah yang sama didapatkan data normalisasi semua alternatif. Hasil normalisasi matrik untuk semua alternatif ditunjukan pada tabel 2.3 .

Tabel 3 Normalisasi Matriks

\begin{tabular}{|l|l|l|l|}
\hline & Kr1 & Kr2 & Kr3 \\
\hline A1 & 0 & 0 & 0 \\
\hline A2 & 0.5 & 1 & 0.3333333 \\
\hline A3 & 1 & 1 & 1 \\
\hline
\end{tabular}

Seperti yang ditunjukkan pada Tabel 2.3, hasil normalisasi matriks pada Vikor juga memiliki range antara $0.00-1.00$. Namun pada Vikor nilai 0.00 merupakan nilai terbaik dalam satu kriteria dan nilai 1.00 adalah nilai terburuk dalam satu kriteria. Sedangkan nilai antara 0.00 sampai 1.00 tidak memiliki keunikan. Hal ini dikarenakan dalam Vikor, nilai dengan indeks terkecil adalah nilai yang terbaik.

Setelah mendapatkan hasil normalisasi untuk semua alternatif, maka langkah selanjutnya adalah mengalikan hasil normalisasi dengan bobot kriteria

Perhitungan nilai normalisasi alternatif A1 $\mathrm{x}$ bobot kriteria.

$$
\begin{aligned}
-\quad(\mathrm{A} 1 \times \mathrm{Kr} 1) & =0.00 \times 0.5=0.00 \\
-\quad(\mathrm{A} 1 \times \mathrm{Kr} 2) & =0.00 \times 0.3=0.00 \\
-\quad(\mathrm{A} 1 \times \mathrm{Kr} 3) & =0.00 \times 0.2=0.00
\end{aligned}
$$

Perhitungan hasil perkalian normalisasi dengan bobot kriteria untuk alternatif lain dilakukan dengan menggunakan cara yang sama. Selanjutnya hasil perkalian normalisasi dengan bobot kriteria untuk semua alternatif dapat dilihat pada tabel 4 .

Tabel 4 Normalisasi x Bobot

\begin{tabular}{|l|l|l|l|}
\hline & $\mathrm{Kr} 1$ & $\mathrm{Kr} 2$ & $\mathrm{Kr} 3$ \\
\hline A1 & 0 & 0 & 0 \\
\hline A2 & 0.25 & 0.3 & 0.66667 \\
\hline A3 & 0.5 & 0.3 & 0.2 \\
\hline
\end{tabular}


Menghitung S

$$
\begin{aligned}
& S_{i}=\sum_{j=1}^{n} w j x(R i j) \\
& w j=\text { bobot } \text { kriteria }
\end{aligned}
$$

Measure

Rumus 2. Utility

Nilai S didapatkan dari penjumlahan hasil perkalian bobot kriteria dengan data normalisasi pada tiap alternatif. Nilai $\mathrm{S}$ didapatkan dengan cara menjumlahkan nilai masing-masing alternatif untuk semua kriteria.

Perhitungan nilai $\mathrm{S}$ untuk alternatif solusi A1 menggunakan Rumus 3.

$S A 1=0.00+0.00+0.00=0.00$

Menghitung R

$\mathrm{Ri}=\operatorname{Max} \mathrm{j}[\mathrm{wj} \mathrm{x} \mathrm{Rij}]$

nilai terbesar dari [wj x Rij]

Measure

Rumus 3. Regret

Sedangkan untuk mendapatkan nilai $\mathrm{R}$ dilakukan dengan cara mencari nilai terbesar dari hasil perkalian normalisasi dengan bobot kriteria berdasarkan masing-masing alternatif.

Nilai R untuk sampel A1 adalah nilai terbesar dari semua kriteria untuk alternatif A1.

$R A 1=0.00$

Dengan langkah yang sama maka akan diperoleh data nilai $\mathrm{S}$ dan $\mathrm{R}$ dari semua alternatif yang ditunjukkan pada Tabel 5 .

Tabel 5 Nilai $\mathrm{S}$ dan $\mathrm{R}$

\begin{tabular}{|l|l|ll|}
\hline Sampel & Nilai S & Nilai R & Alur k \\
\hline A1 & 0 & 0 & Gamba \\
\hline A2 & 0.61667 & 0.3 & \\
\hline A3 & 1 & 0.5 & \\
\hline
\end{tabular}

Pada Tabel 5, untuk masing-masing kolom S dan $\mathrm{R}$ terdapat nilai data yang digaris bawahi dan ditebalkan, serta terdapat nilai data yang diberi warna merah dan dimiringkan. Nilai yang digaris bawahi dan ditebalkan merupakan nilai terbesar yaitu 1 untuk nilai $\mathrm{S}$ terbesar dan 0.5 untuk nilai $\mathrm{R}$ terbesar. Sedangkan nilai yangdiberi warna merah dan dimiringkan merupakan nilai terkecil untuk masingmasing nilai $S$ yaitu 0 dan $R$ yaitu 0 .

Menghitung Indeks Vikor

$$
Q_{i}=\left[\frac{S i-s^{\prime}}{s *-s^{\prime}}\right] x v+\left[\frac{R i-r^{\prime}}{R *-R^{\prime}}\right] x(1-v)
$$

Vikor

Rumus 4. Index

Keterangan :

$\mathrm{S}^{\prime}=$ nilai $\mathrm{S}$ terkecil

$\mathrm{S}^{*}=$ nilai $\mathrm{S}$ terbesar

$\mathrm{R}^{\prime}=$ nilai $\mathrm{R}$ terkecil
$\mathrm{R}^{*}=$ nilai $\mathrm{R}$ terbesar

Setelah mendapatkan nilai $\mathrm{S}$ dan $\mathrm{R}$, langkah terakhir adalah mendapatkan nilai $Q$ dengan menggunakan Rumus 4. Alternatif dengan nilai Q terkecil merupakan alternatif terbaik.

Perhitungan nilai index vikor (Q) alternatif A1.

$$
Q_{A 1}=\left[\frac{0-0}{1-0}\right] x 0.5+\left[\frac{0-0}{0.5-0}\right] X(1-0.5)=0
$$

Dari perhitungan menggunakan Rumus 4 nilai index Vikor pada halaman 43 (nilai Q) untuk alternatif $\mathrm{A} 1$ adalah 0 dan perhitungan nilai index Vikor (Q) untuk semua alternatif dengan langkah yang sama ditunjukkan pada Tabel 2.6.

Tabel 2.6 Indeks Vikor dan Ranking

\begin{tabular}{|l|l|l|l|l|}
\hline Sampel & Nilai S & Nilai R & Nilai Q & Ranking \\
\hline A1 & 0 & 0 & 0 & 1 \\
\hline A2 & 0,616667 & 0.3 & 0.608333 & 2 \\
\hline A3 & 1 & 0.5 & 1 & 3 \\
\hline
\end{tabular}

Nilai index Vikor (nilai Q) terkecil merupakan alternatif terbaik sehingga berdasarkan hasil perhitungan, peringkat pertama adalah alternatif A1 memiliki nilai index Vikor (nilai Q) terkecil yaitu 0, alternatif A2 berada pada peringkat kedua dengan nilai index Vikor (nilai Q) 0.608333 serta alternatif A3 berada pada peringkat terakhir dengan nilai index Vikor (nilai Q) 1.

Proses ini dibangun bertujuan untuk mencari solusi dari permasalahan kerusakan hardware komputer dan memberikan solusi berdasarkan ranking. Ranking dilihat dari tingkat kemudahan, biaya yang dikeluarkan, dan terbanyak dilakukan. Alur kerja dari sistem pakar ini dapat dilihat pada Gambar2.

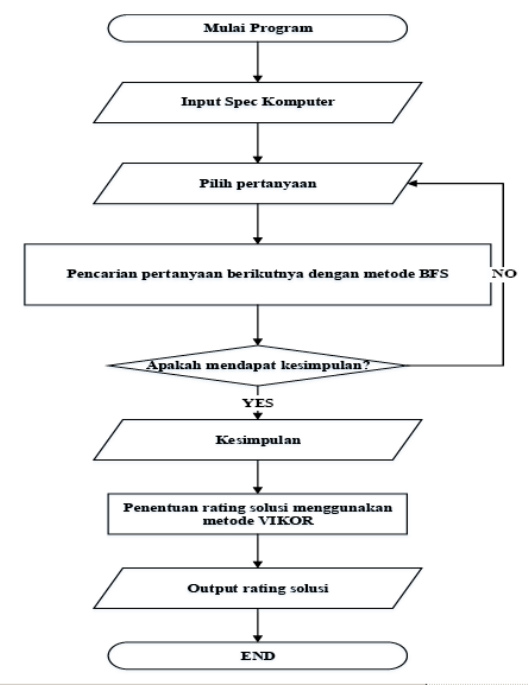

Gambar 2Flowchart System Aplikasi Diagnosa Kerusakan Hardware

Alur kerja sistem ini dimulai dengan melakukan 
input spesifikasi komputer atau laptop yang nantinya akan digunakan untuk memajukan aplikasi yang dibuat, lalu memilih jenis kerusakan apakah itu hardware atau jaringan. Lalu proses selanjutanya adalah menampilkan hasil atau kesimpulan dengan metode Breadth First Search. Proses pencarian dapat dilakukan berulang-ulang sampai tidak menemukan titik temu pada program dan berakhir dengan peringatan error. Kemudian proses berikutnya akan melakukan pengurutan nilai pada solusi dengan metode Vikor.

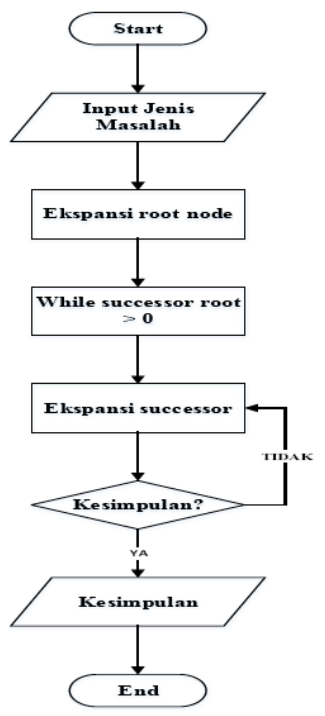

Gambar 3Flowchart Metode Breadth First Search

Seperti pada Gambar 3, alur kerja Breadth First Search dimulai dari pemilihan kepala pohon untuk memulai pencarian selanjutnya. Kepala pohon di pilih oleh user yang menggunakan sistem, lalu sistem akan mencari akar-akar pohon setelah kepala pohon dipilih, jika tidak mendapat penyelesaian dengan menemukan akar masalah yang tepat, metode ini akan mencari akar-akar dari kepala pohon lain dan memberikan solusi sesuai dengan kepala akar yang di temukan.

Proses Vikor dimulai dengan pengambilan nilai alternatif dan nilai bobot kriteria lalu dilakukan pencarian nilai terbesar dan terkecil dari setiap kriteria untuk digunakan dalam proses normalisasi dengan menggunakan rumus. Hasil normalisasi tersebut akan dikalikan dengan bobot kriteria berdasarkan masing-masing kriteria dan dari hasil perkalian tersebut akan dihitung nilai Utility Measure dengan rumus dan Regret Measure dengan rumus. Nilai Utility Measure merupakan nilai penjumlahan dari hasil perkalian normalisasi dengan bobot kriteria untuk setiap alternative, sedangkan nilai Regret Measure merupakan nilai terbesar dari hasil perkalian normalisasi dengan bobot kriteria untuk masingmasing alternatif. Selanjutnya adalah menghitung nilai Index Vikor dengan menggunakan rumus dan penentuan urutan dilakukan berdasarkan nilai Index Vikor terkecil seperti yang ditunjukkan Gambar 4.

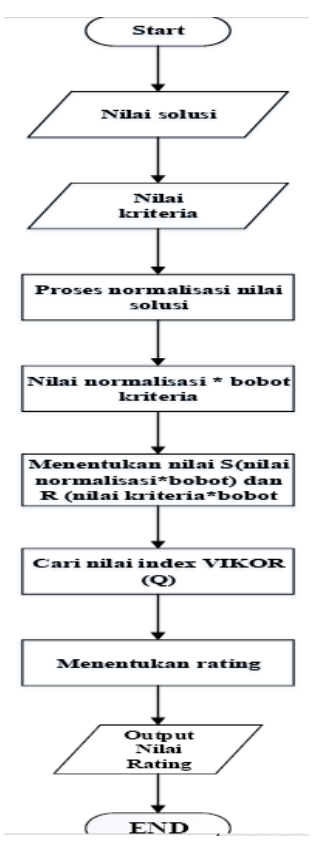

Gambar 4 Flowchart Metode Vikor

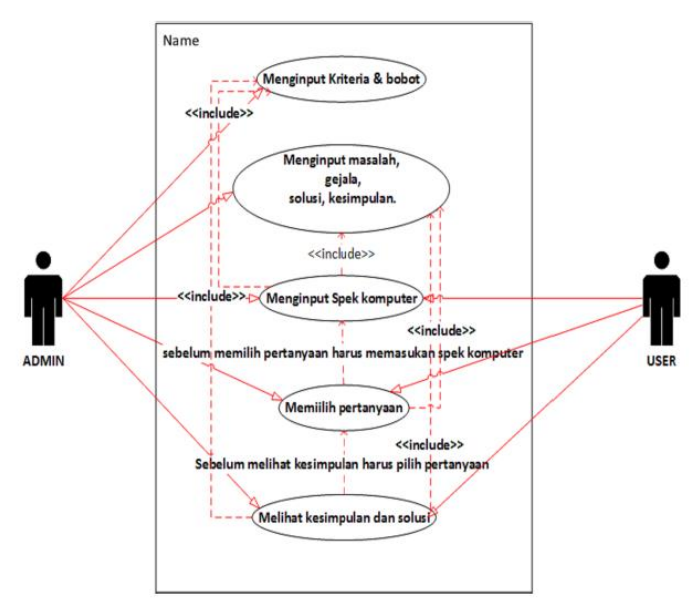

Gambar 5 Use Case Diagram Aplikasi Diagnosa Kerusakan Hardware.

Admin dan User adalah aktor, sedangkan fitur yang ada pada sistem digambarkan dengan use case yang ada di dalam system boundary. Pada sistem ini admin dapat melakukan input kriteria dan bobot serta input masalah dan gejala kerusakan pada hardware komputer. Nilai dan masalah yang sudah masukan akan disimpan pada database dan akan dipanggil dalam proses pencarian solusi dilakukan dan pengurutan nilai pada saat proses pemilihan solusi. Setelah prosespencarian solusi dengan metode Breadth First Search maka akan muncul proses rating solusi terbaik oleh metode Vikor. 


\section{RESULT AND ANALYSIS}

Berikut sepotong pseudocode dari Vikor

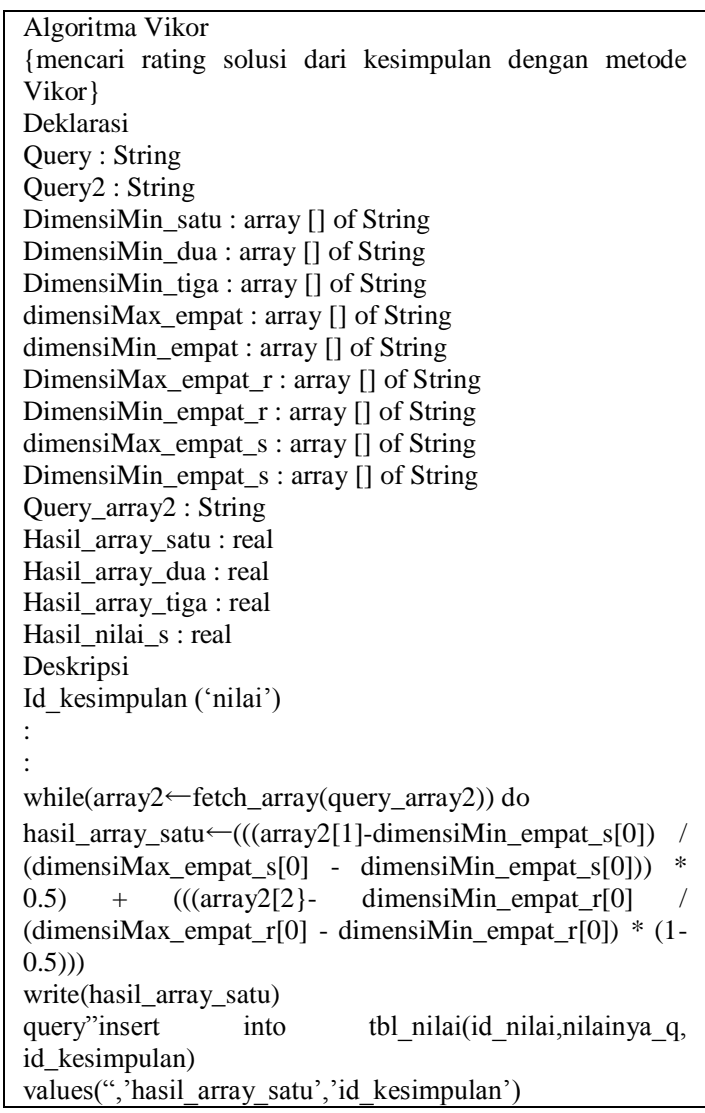

Gambar 6 Pseudocode Vikor

Seperti Gambar 6pseudocode Vikor berfungi untuk mencari rating solusi berdasarkan nilai $\mathrm{Q}$ yang memiliki range dimulai $0-1$. Langkah pertama adalah mengambil nilai yang ada pada setiap solusi yang dimasukan admin, kemudian mencari nilai max dan nilai min dari setiap nilai untuk masing-masing kriteria yang akan digunakan untuk proses normalisasi.

Setelah mendapatkan nilai normalisasi maka langkah selanjutnya adalah mencari nilai $\mathrm{S}$ dan $\mathrm{R}$. Nilai tersebut didapatkan dari hasil perkalian nilai normalisasi dengan nilai bobot kriteria. Langkah terakhir adalah mendapatkan nilai index vikor (nilai Q) dengan menggunakan nilai $\mathrm{S}$ dan $\mathrm{R}$ yang sudah didapatkan sebelumnya dan mengacu pada Rumus Index Vikor. Nilai Q terkecil merupakan solusi dengan rating terbaik sedangkan nilai $Q$ terbesar adalah solusi terburuk.

Berikut sepotong pseudocode dari Breadth First Search :

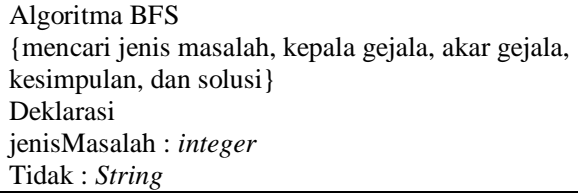

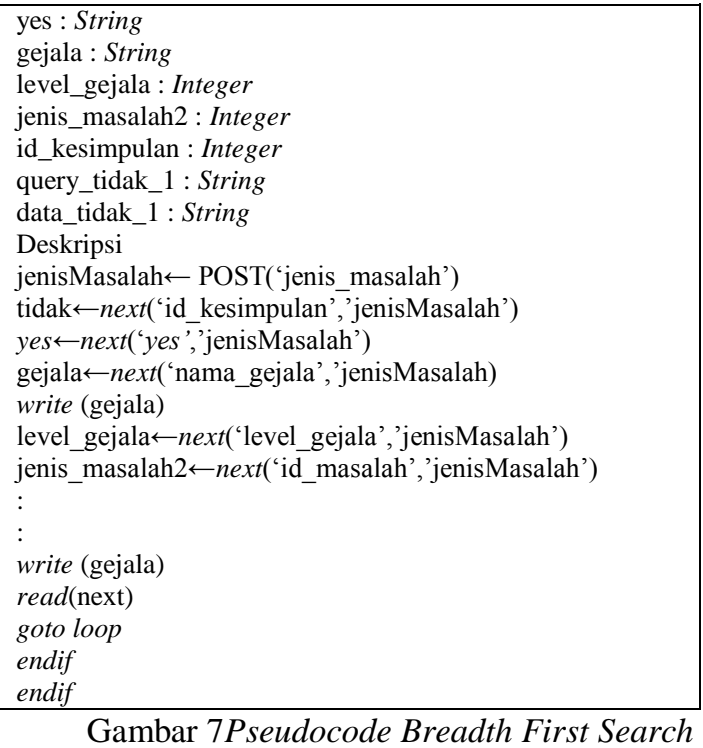

Seperti pada Gambar 7Pseudocode Breadth First Search berfungsi mencari solusi melalui proses pencarian gejala. Setiap gejala memiliki nilai yang akan dipakai pada proses pencarian. Proses pertama sistem akan mencari ID gejala yang berada pada pohon gejala, kemudian akan mencari ID gejala berikutnya yang berada pada pohon gejala sampai node terakhir yang menentukan kesimpulan.

Dari ID kesimpulan akan didapat ID solusi yang akan ditampilkan pada sistem beserta rating solusi. Jika node yang dicari tidak ditemukan maka sistem akan menampilkan peringatan bahwa masalah yang dicari oleh user tidak ditemukan dan akan mengulang kembali proses dari awal.

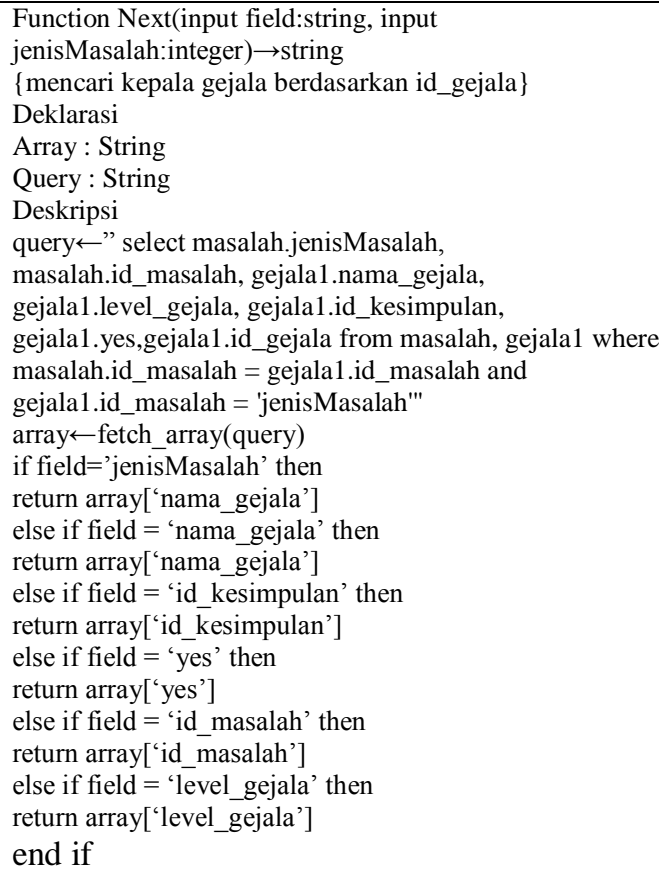

Gambar 8Pseudocode Function Next 
Seperti Gambar 8 Pseudocode Function Next berfungsi mencari gejala melalui proses pencarian. Setiap gejala memiliki nilai yang akan dipakai pada proses pencarian. Proses pertama sistem mencari ID gejala yang berada pada pohon gejala. Proses kedua sistem mencari ID gejala berikutnya yang berada pada pohon gejala sampai node terakhir yang menentukan kesimpulan. Proses ketiga sistem mencari node lain jika belum menemukan kesimpulan.

Berdasarkan penelitian yang penulis lakukan, penulis dapat mengimplementasikan hasil analisis yang telah dilakukan kedalam sebuah aplikasi. Berikut salah satu halaman pada aplikasi yang penulis implementasikan :

A. Halaman Input Jenis Masalah

Halaman input jenis masalah merupakan form yang dapat menambahkan jenis masalah dan langsung dimasukan ke dalam tabel sebagai tampilan setelah ditambahkan.

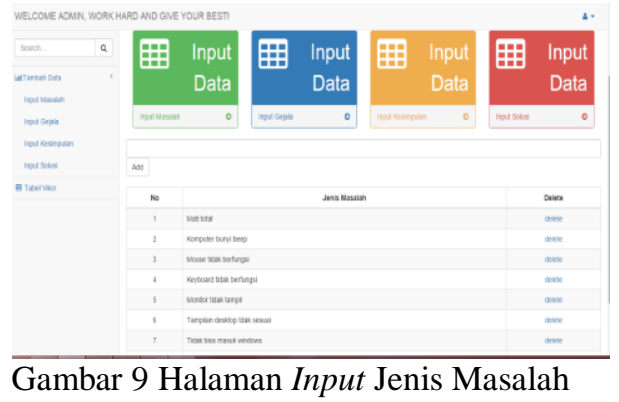

B. Halaman Input Gejala

Halaman ini berfungsi untuk menambahkan gejala dan memasukannya ke dalam database kemudian akan ditampilkan dalam bentuk tabel di dalamwebsite seperti pada Gambar 10.

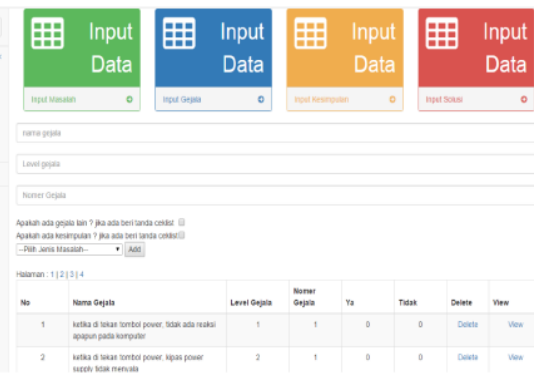

Gambar 10 Gambar Input Gejala

C. Halaman Input Kesimpulan

Halaman input kesimpulan memiliki fitur menambahkan kesimpulan, kemudian menambahkan level gejala yang berfungsi untuk menjalankan metode pencarian seperti pada Gambar 11.

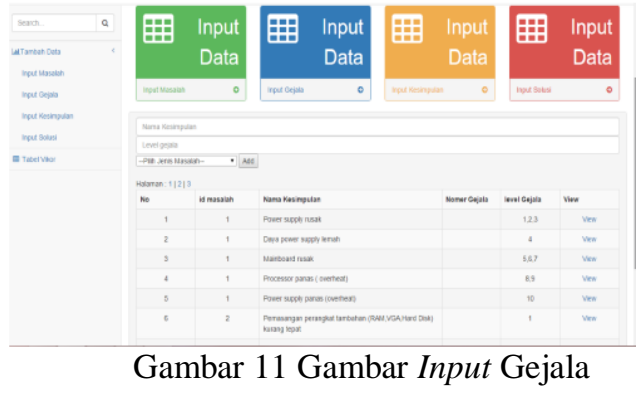

D. Halaman Input Solusi

Pada halaman ini program dapat menambahkan solusi baru yang akan di input, nilai kriteria yang akan berfungsi untuk menghitung ranking di dalam program, level solusi berfungsi untuk membantu proses pencarian pada metode Breadth First Search, dan terakhir adalah rows_id yang berguna untuk menempatkan urutan solusi pada tampilan seperti Gambar 12.

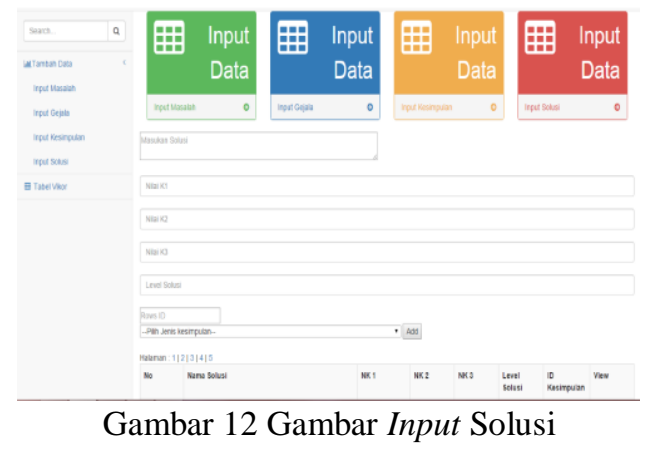

E. Halaman Implementasi Tabel Vikor

Halaman tabel Vikor ini berfungsi untuk menjalankan proses perhitungan metode Vikor. Metode Vikor ini dijalankan dalam proses secara manual untuk mencegah admin yang lupa memasukan nilai pada setiap kriteria seperti pada Gambar 13.

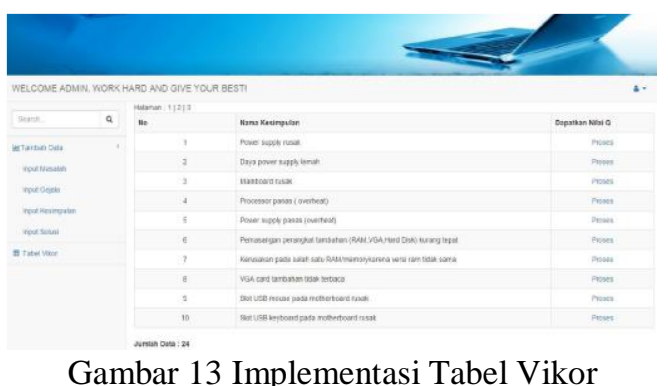

\section{CONCLUSION AND EXPRESSION}

Berdasarkan hasil penelitian yang telah dibuat, maka dalam penelitian pembuatan aplikasi ini dapat diambil kesimpulan yaitu Algoritma Breadth First Search merupakan algoritma yang sesuai untuk aplikasi diagnosa karena algoritma ini akan berjalan terus untuk menemukan solusi atau dengan kata lain 
algoritma ini pasti akan menemukan solusi yang dicari oleh user jika sesuai dengan database dan metode VIKOR merupakan metode yang sesuai untuk sistem rating karena metode ini mengurutkan dengan menggunakan rumus dan menghitung nilai dari solusi pada sistem pakardengan tingkat kesamaan rekomendasi solusi terbaik adalah $99 \%$ sesusai dengan rekomendasi ahli.

\section{REFERENCE}

[1] Budiharto, Widodo, Suhartono, Derwin. Artificial Intelligence Konsep dan Penerapannya, Yogjakarta. 2014

[2] C.E. Leiserson and T.B. Schardl. A worke_cient parallel breadth first search algorithm (or how to copet with the nondeterminism of reducers). In Proc. 22nd ACM Symp. on
Parallism in Algorithms Ana Architectures (SPAA '10), June 2010.

[3] Datta, Saurav., Siba Sankar Mahapatra, Sabhyasachi Banerjee, Asish Bandyopadhyay. Comparative Study on Application of Utility Concept and VIKOR Method for Vendor Selection, AIMS International Conference on Value-based Management, 2010.

[4] Khezrian, M,. Kadir,. Wan M. N. Wan,. Suhaimi Ibrahim, and Alaeddin Kalantari. Service Selection based on VIKOR method, International Journal of Research and Reviews in Computer Science (IJRRCS) Vol. 2, No. 5, October 2011, ISSN: 2079-2557.

[5] Serafim Opricovic and Gwo Hshiung Tzeng. Extended Vikor Method in Comparison with Outranking Methods, European Journal of Operational Research. 2006. 